\title{
Analysis of Heavy Metal Content in the Dry Matter of Different Energy Crops
}

\author{
Edgars Cubars ${ }^{1}$, Liena Poisa ${ }^{2}$, Gotfrids Noviks ${ }^{1}$, Rasma Platace ${ }^{2}$, Skaidrite Bumane ${ }^{3}$ \\ ${ }^{1}$ Institute for Regional studies, Rezekne Higher Education Institution, \\ Atbrīvošanas aleja 115/k-4, Rezekne,LV-4600,Latvia, \\ e-mail:edgars.cubars@inbox.lv; Gotfrids.Noviks@ru.lv \\ ${ }^{2}$ Latvian University of Agriculture, \\ Liela iela 3, Jelgava,LV-3000,Latviae-mail: lienapoisa@inbox.lv; rasmins@inbox.lv \\ ${ }^{3}$ Latvian Plant Protection Research Centre, \\ Struktoru iela 14a, Riga, LV-1039,Latvia, e-mail: skbumane@inbox.lv
}

\begin{abstract}
The study shows results of research on heavy metal concentration in the biomass of common reed, hemp and reed canary grass. Research of common reed was performed in winter from 2010 until 2012 in 11 natural and artificial water bodies of Latvia. Samples of hemp and reed canary grass collected in the spring of 2009 and 2010 were analysed.

Analysis of the collected samples of common reed allowed detecting heavy metal content $(\mathrm{Cd}, \mathrm{Pb}, \mathrm{Cu}, \mathrm{Ni}, \mathrm{Fe})$ in the biomass. Studies of samples of hemp and reed canary grass revealed that $\mathrm{Cd}$ and $\mathrm{Pb}$ were present in the biomass. Basing on these results, suitability of the plant biomass for energy production was analyzed.

Heavy metal content in the common reed biomass complies with the requirements of solid biofuel. Common reed from all the reed beds of Latgale region can be collected in one place and used for the production of fuel. Removal of common reed would help to reduce the concentration of heavy metals in natural waters and sediment of the reed beds.

The content of heavy metals in the samples of hemp and reed canary grass was periodically analysed. It was found out that in some of the research samples the amount of heavy metals exceeded the maximum acceptable concentrations for fuel.
\end{abstract}

Keywords: common reed, heavy metals, solid biofuels, reed beds.

\section{INTRODUCTION}

Common reed (Phragmites australis (Cav.) Trin. $=$ Ph. communis Trin. $=$ Arundo phragmites $L)$ is a perennial plant of the cereal grass family, and it is one of the most widely spread plants worldwide $[1 ; 2]$. The common reed can be used for energy production $[3 ; 4]$.

Common reed, similarly to other plants in different growth stages actively absorbs nutriments from water, which helps to reduce environmental pollution $[5 ; 6$; 7]. Artificial common reed plantations are useful for effluent water treatment and purification. $[8 ; 9 ; 10 ; 11$; 12]. Common reed absorbs heavy metals well. [13; 14; $15 ; 16 ; 17]$. Heavy metals are very dangerous for natural ecosystems. One of the methods used for removal of heavy metals from natural waters is phytoremediation, i.e. the use of plants to remove heavy metals from water bodies $[18 ; 19 ; 20]$. The common reed is suitable for removal of heavy metals, therefore its harvesting would help the purification of water bodies from heavy metals. One of the aims of the research is to establish the amount of heavy metals that can be removed from water bodies, by cutting the common reed above the ice in winter. On the other hand, it is not known if the heavy metal content in the common reed does not exceed the maximum allowed concentration (MAC) for biofuel. Similarly to the common reed that removes heavy metals from water bodies and sediments, hemp and reed canary grass take up heavy metals from the soil. Thus, the biomass of these plants can contain heavy metals, therefore it is necessary to examine this issue.

The content of heavy metals in the biomass used for fuel production is limited by various standards. Suitability of reed biomass has been evaluated according to the German standard DIN 5173 and EC standard prEN $14961-3$ that specify the maximum acceptable concentrations (MAC) of heavy metals in solid biofuel.

\section{MATERIALS AND METHODS}

In order to inspect the areas of common read, in each of the investigated lakes four reed stands were chosen that visually corresponded to the characteristic 
parameters of the average reeds found in the specific water body. For each stand two sampling plots were investigated. About $1 \mathrm{~kg}$ of the common reed biomass was taken from each sampling plot, and it was used for determination of the parameters in laboratory conditions. However, previous research has shown that the stalks and leaves of common reed have different capacities of accumulation of heavy metals [21].

In this research the stalks and leaves of common reed were not separated because harvesting of common reed for the production of biofuel and separating would be complicated and energy capacious, which would increase the cost of the common reed processing. The samples of common reed collected from the 8 sampling plots in each lake were combined to form an average sample. The reeds were chopped up, and for the laboratory research $1 \mathrm{~kg}$ was taken of the average sample.

Reed canary grass (RCG) varieties 'Marathon' and 'Bamse' were cultivated in sod-podzolic loamy soil (the organic content of the soil $-5.2 \%, \mathrm{pH} \mathrm{KCl}-5.8$, $\mathrm{P}_{2} \mathrm{O}_{5}-20 \mathrm{mg} \cdot \mathrm{kg}^{-1}$, and $\mathrm{K}_{2} \mathrm{O}-90 \mathrm{mg} \mathrm{kg}{ }^{-1}$ of the soil) in the Agricultural Science Centre of Latgale. The area of plots was $16 \mathrm{~m}^{2}$, the location of the plots was randomized. The RCG was sown after a bare fallow. Before sowing a complex fertilizer was applied $\mathrm{N}: \mathrm{P}: \mathrm{K}-5: 10: 25$ - $400 \mathrm{~kg}^{*} \mathrm{ha}^{-1}$. The RCG varieties 'Marathon' and 'Bamse' were sown in April 2009 and 2010. The local hemp 'Pūrini' (Cannabis sativa L.) is an annual crop from the Cannabinaceae family which has been cultivated in Latvia for more than 200 years. Hemp trials (varieties 'Pūriņi' and 'Bialobrzeskie') were on the sod gleisoil soil (organic matter content $35-38 \mathrm{~g} \mathrm{~kg}^{-1}, \mathrm{pH}$ KCI 7.0 - 7.3, available plant phosphorus content $-83-145 \mathrm{mg} \mathrm{kg}^{-1} \mathrm{P}_{2} \mathrm{O}_{5}$, changes in the potassium content $-65-118 \mathrm{mg} \mathrm{kg}^{-1} \mathrm{~K}_{2} \mathrm{O}$ ). The samples for the laboratory research were gathered in April 2009 and 2010.

To establish the heavy metal content in the biomass samples, mineralization was undertaken by using the following methodology: biomass samples were reduced to fragments $<150 \mu \mathrm{m}$ by using a mill, and then producing a sample of $1.5 \mathrm{~g}$. Then $15 \mathrm{ml}$ concentration $\mathrm{HNO}_{3}$ was added, and the sample was heated to $95{ }^{\circ} \mathrm{C}$ temperature over a period of 2 hours. The cooled sample was strained through a filter, which had been previously washed with $0.5 \% \mathrm{HNO}_{3}$, and diluted with deionized water up to $65 \mathrm{ml}$.

The metal content in the solution was determined by optical plasma emission spectrometer Perkin Elmer Optima 2100 DV. The data procured were recalculated for $\mathrm{mg}^{*} \mathrm{~kg}^{-1}$ dry matter.

\section{RESULTS AND DISCUSSION}

Amount of $\mathrm{Cd}$ in the reed biomass was relatively small and varied within limits of $0-0.28 \mathrm{mg}^{*} \mathrm{~kg}^{-1}$, which was below MAC in all the lakes under research (see Figure 1). Cd content in forestry production waste is $0.1-0.2 \mathrm{mg}^{*} \mathrm{~kg}^{-1}$ [22] which indicates that the $\mathrm{Cd}$ content is similar in reed biomass and fire wood. The Cd substance output from reeds comprised $0-0.20$ $\mathrm{mg}^{*} \mathrm{~m}^{-2} * \mathrm{year}^{-1}$, which was higher than from reeds in sewage treatment plants [21], where it consisted of $0.014-0.038 \mathrm{mg}^{*} \mathrm{~m}^{-2} *$ year $^{-1}$, which shows that $\mathrm{Cd}$ absorption in reed stalks depends on its content in water and sediment.

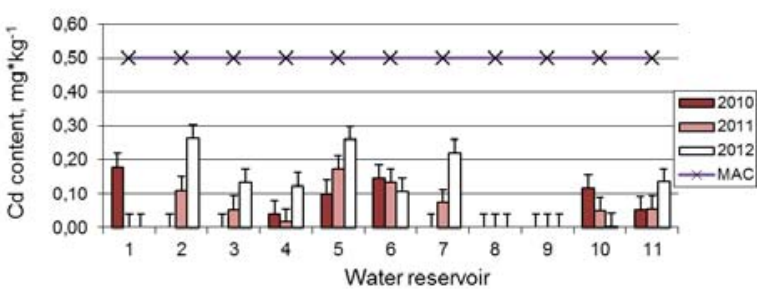

1-Lubanas lake, 2-Kvapanu ponds, 3-Idenas ponds, 4-Luknas lake, 5-Cirisa lake, 6-Sivera lake, '7-Rusonas lake, 8-Feimanu lake, 9Raznas lake, 10- Cirmas lake, 11-L.Ludzas lake.

Fig. 1. Cd content average values in winter for the reed biomass harvested above ice level in the lakes of Latgale

In all the researched water reservoirs, $\mathrm{Cd}$ content in reed biomass significantly changed according to the harvesting year, which shows a high Cd compound mobility in natural waters that has been described in another research [23; 24]. In Feimanu and Raznas lakes no traces of $\mathrm{Cd}$ have been found in the reed biomass for years of research, in Lubanas lake Cd was found in 2010 in the reed biomass, but not in 2011 or 2012. In Kvapanu and Idenas ponds no Cd was found in the research samples of reed biomass in 2010, but was found in 2011 and 2012. In another lakes Cd was found in various concentrations every year, which shows a high $\mathrm{Cd}$ compound mobility in natural waters. $\mathrm{Cd}$ content was different in the reeds harvested from different lakes, although it did not exceed the MAC, as a result one can assume that the reeds from different lakes can be mixed together as a fuel.

$\mathrm{Cd}$ in the hemp samples was not found in any of the years of investigation, thus it can be deduced, that, in terms of $\mathrm{Cd}$ content, the hemp biomass is suitable for biofuel production. In the samples of 2010, in the reed canary grass $\mathrm{Cd}$ was established for both researched varieties, which comprised $1.85 \mathrm{mg}^{*} \mathrm{~kg}^{-1}$ for the variety "Marathon" dry mass and $1.18 \mathrm{mg}^{*} \mathrm{~kg}^{-1}$ for the variety "Bamse", which exceeded MAC $\left(0.5 \mathrm{mg} *^{-1} \mathrm{~kg}\right)$ However, in the samples of $2009 \mathrm{Cd}$ compounds were not observed. Such variation in $\mathrm{Cd}$ presence indicates to a high degree of $\mathrm{Cd}$ mobility. $\mathrm{Cd}$ content can cause problems of compliance with quality standards when using reed canary grass as biofuel.

$\mathrm{Pb}$ content in the dry matter of reed biomass varied within the limits of $0-1.81 \mathrm{mg}^{*} \mathrm{~kg}^{-1}$ and in none of the researched lakes it exceeded MAC. $\mathrm{Pb}$ content in forestry production waste is $2-5 \mathrm{mg} \mathrm{mg} * \mathrm{~kg}^{-1}$, [22] which makes one conclude that the $\mathrm{Pb}$ content in the 
reed biomass is lower than in the forestry production waste. In this research, $\mathrm{Pb}$ in the reed substance was $0-1.27 \mathrm{mg}^{*} \mathrm{~m}^{-2} *$ year $^{-1}$, which varied over a wider range than for reeds that are used for sewage treatment [21] where the substance value for $\mathrm{Pb}$ is $0.36-0.44 \mathrm{mg}^{*} \mathrm{~m}^{-2} *$ year $^{1}$. In all the researched water reservoirs, except for Lukna and Cirisa lakes, the $\mathrm{Pb}$ content in the reed biomass changed significantly according to the harvesting year. In Lubanas lake, $\mathrm{Pb}$ has not been detected in the read biomass in any of the years (Fig. 2).

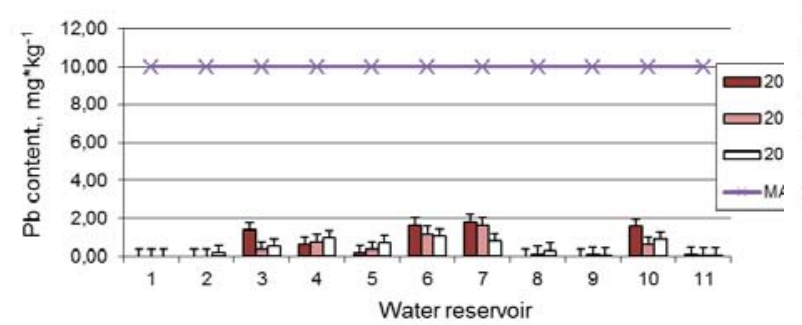

1-Lubanas lake, 2-Kvapanu ponds, 3-Idenas ponds, 4-Luknas lake, 5-Cirisa lake, 6-Sivera lake, 7- Rusonas lake, 8-Feimanu lake, 9Raznas lake, 10-Cirmas lake,11-L.Ludzas lake.

Fig. 2. $\quad \mathrm{Pb}$ content average values for the reed biomass harvested above ice in the lakes of Latgale

The $\mathrm{Pb}$ content varied significantly among the reeds of different lakes, even though it did not exceed the MAC in the researched lakes, and therefore is can be assumed that the harvested reeds can be mixed together and used as fuel.

$\mathrm{Pb}$ content in hemp biomass was established while studying both samples of 2009 . $\mathrm{Pb}$ content for the variety "Purini" comprised $14.97 \mathrm{mg}{ }^{*} \mathrm{~kg}^{-1}$ of the dry mass, but for the variety "Bialobrzeskie" $11.23 \mathrm{mg} * \mathrm{~kg}$ ${ }^{-1}$ of the dry mass, which exceeds the MAC for biofuel $\left(10 \mathrm{mg}^{*} \mathrm{~kg}^{-1}\right)$. In $2010 \mathrm{~Pb}$ was not established in the samples taken.

In the reed canary grass samples of $2009 \mathrm{~Pb}$ was not established, however in 2010 the level of $\mathrm{Pb}$ - for the variety "Marathon" $35.4 \mathrm{mg} * \mathrm{~kg}^{-1}$ in the dry mass, but for the variety "Bamse" $22.1 \mathrm{mg}^{*} \mathrm{~kg}^{-1}$ in the dry mass. The different $\mathrm{Pb}$ concentrations in different years can be explained by the influence of climatic conditions. A higher $\mathrm{Pb}$ concentration in hemp and reed canary grass could cause problems with conformity to standards. The heavy metal content and influencing factors in hemp and reed canary grass need to be researched further, in order to clarify the causes of their formation in the biomass. Ni content in the reed biomass varied within limits of $0.29-2.06$ $\mathrm{mg}^{*} \mathrm{~kg}^{-1}$, in all the research water reservoirs it was about five times lower than the MAC. Ni content in forestry production waste was $0.5 \mathrm{mg}^{*} \mathrm{~kg}^{-1}$ [22] which indicates that the $\mathrm{Ni}$ content in the reed biomass is on average three times greater than the $\mathrm{Ni}$ content for fire wood, although it does not exceed the MAC. The output of reed $\mathrm{Ni}$ substance was $0.2-1.44 \mathrm{mg}^{*} \mathrm{~m}$ ${ }^{2}$ year $^{-1}$, which varied within a wider range, than for reeds used in sewage treatment plants [21] where the Ni substance output was $0.57-0.91 \mathrm{mg}^{*} \mathrm{~m}^{-2}$ year $^{-1}$, $\mathrm{Ni}$ compounds were found in all the analyzed samples. In Lubanas lake, Idenas ponds and Cirisa lake significant differences were detected in the reed biomass for $\mathrm{Ni}$ content in the samples taken in different years. In the other researched lakes, Ni content in the reed biomass did not change significantly depending on the harvesting year (Fig. $3)$.

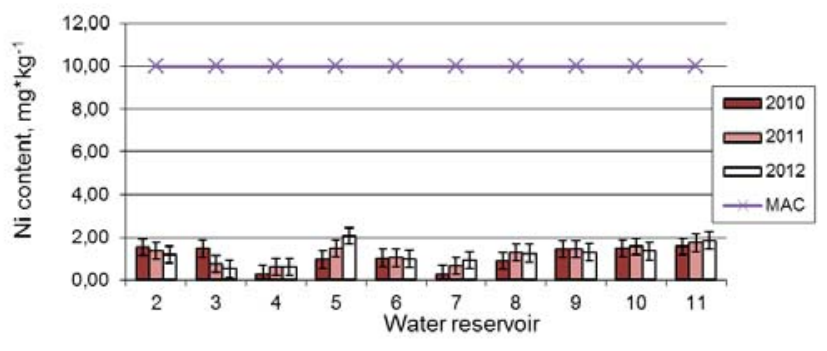

1-Lubanas lake, 2-Kvapanu ponds, 3-Idenas ponds, 4-Luknas lake, 5-Cirisa lake, 6-Sivera lake, 7-Rusonas lake, 8-Feimanu lake, 9Raznas lake, 10-Cirmas lake, 11-L.Ludzas lake.

Fig. 3. Ni content average values in winter in the reed biomass harvested above ice in the lakes of Latgale

$\mathrm{Ni}$ content varies among the reeds harvested in different lakes, however in none of the researched lakes it did not exceed the MAC, therefore one can assume, that the reeds collected from various lakes can be mixed together and used for fuel.

$\mathrm{Cu}$ content in the reed biomass varied within the limits of $2-5 \mathrm{mg}^{*} \mathrm{~kg}^{-1}$ which comprised up to $50 \%$ of the MAC biomass fuel. $\mathrm{Cu}$ content in forestry production waste amounts to about $2 \mathrm{mg}^{*} \mathrm{~kg}^{-1}$ [22] which indicates that the reed biomass contains on average 1.5 times more $\mathrm{Cu}$ than the forestry production waste however it is still within the MAC limits. The reed plant $\mathrm{Cu}$ substance output was $1.4-$ $3.5 \mathrm{mg}^{*} \mathrm{~kg}^{-1} *$ year ${ }^{-1}$ which is about two times less than the amount established in the reed biomass of sewage treatment plants [21].

The ability of reeds to absorb $\mathrm{Cu}$ from natural water bodies and sediments depends on the $\mathrm{Cu}$ compound concentration in them. By harvesting 1 ha of reeds from the water it is possible to remove $138-$ $148 \mathrm{~g} \mathrm{Cu}$. The $\mathrm{Cu}$ substance output in another research [14] where reed stalks were harvested was $570 \mathrm{~g}$ for 1ha, which shows that reed stalks have a good capacity of absorption of $\mathrm{Cu}$, which confirms the findings of the previous research [24].

$\mathrm{Cu}$ compounds were noted in all the analyzed samples. In terms of $\mathrm{Cu}$ content in Lukna, Sivers and Cirma lakes there were no significant differences between the samples taken over different years, in the other lakes the $\mathrm{Cu}$ content varied in the reed biomass according to the harvesting year, which shows high $\mathrm{Cu}$ mobility in natural waters, although in none of the 
research samples did the $\mathrm{Cu}$ content exceed the MAC (Fig. 4).

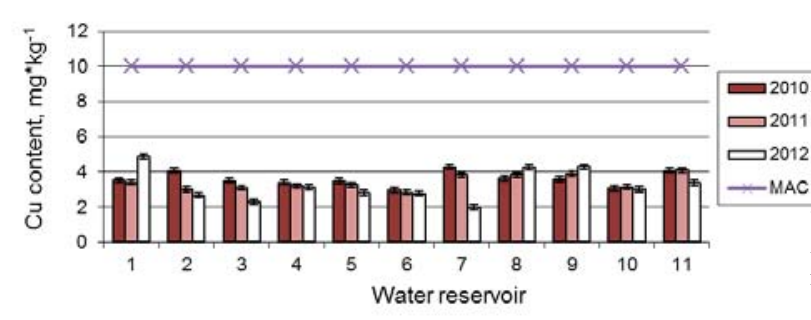

1-Lubanas lake, 2-Kvapanu ponds, 3-Idenas ponds, 4Luknas lake, 5-Cirisa lake, 6-Sivera lake, 7-Rusonas lake, 8Feimanu lake, 9-Raznas lake, 10-Cirmas lake,11-L.Ludzas lake.

Fig. 4. $\mathrm{Cu}$ average content in winter in the reed biomass harvested in the lakes of Latgale

$\mathrm{Cu}$ content was different in the reeds harvested from different lakes, although it did not exceed MAC in any of the researched lakes, which allows concluding that the reeds extracted from various lakes can be mixed together and used as fuel.

Fe compounds were detected in all the analyzed samples. Fe content in reed biomass varied within limits of $12.9-42.4 \mathrm{mg}^{*} \mathrm{~kg}^{-1}$ (Fig. 5), $\mathrm{Fe}$ concentration is not limited by analyzed standards.

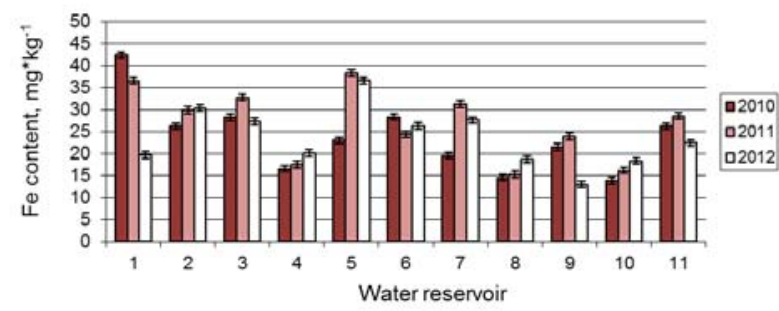

1-Lubanas lake, 2-Kvapanu ponds, 3-Idenas ponds, 4-Luknas lake, 5-Cirisa lake, 6-Sivera lake, 7-Rusonas lake, 8-Feimanu lake, 9Raznas lake, 10-Cirmas lake,11-L.Ludzas lake.

Fig. 5. Fe average content in winter in the reed biomass harvested in lakes of Latgale

The Fe substance output from reeds amounted to $3.7-12.1 \mathrm{mg}^{*} \mathrm{~m}^{-2 *} \mathrm{year}^{-1}$, and this result was higher than results provided by another elements. $\mathrm{Fe}$ absorption in reed stalks depends on its concentration in water and sediment.

\section{CONCLUSION}

Heavy metals were found in all the common reed samples, in all the researched years. The content of heavy metals essentially changes depending on the harvesting year, which shows a high degree of heavy metal mobility in nature.

The analyzed heavy metal content in the common reed biomass corresponds to the requirements of solid biofuel. The common reed can be collected from all the water bodies of Latgale region in one location and used for the production of biofuel. Harvesting of the common reed would reduce the content of heavy metals in the natural water and water body sediments.

While studying the hemp biomass, it was established that $\mathrm{Pb}$ content exceeded MAC in 2 samples, which can cause problems related to compliance of biofuel with the set standards.

While studying the reed canary grass biomass, it was established that $\mathrm{Pb}$ exceeded MAC in 2 samples, and that the amount of $\mathrm{Cd}$ exceeded $\mathrm{MAC}$ in 2 samples as well, which can produce problems related to compliance of biofuel with the set standards. The problem can be solved by producing composite biofuels from various types of biomass.

\section{$\mathrm{V}$ REFERENCES}

1. Brix H. Genetic diversity, ecophysiology and growth dynamics of reed (Phragmites australis). In: Aquatic Botany 64, 1999, pp. 179-184.

2. Lambertini C., Brix H., Speranza M. Clonal variability of the Common reed Phragmites australis (Cav.) Trin ex. Studel, in the Po plain. In: Agroindustria Vol.2 (2/3), 2003, pp. 121-126.

3. Komulainen M., Simi P.,Hagelberg E., Ikonen I., Lyytinen S Reed energy-Posibilities of using the Cammon Reed for energy generation in Southern Finland. In: Turku university of applied sciences reports 67. 2008, pp. 5-75.

4. Reed up on Reed Ikkonen I., Roosaluste E., Pitkanen T.at.al. Southwest Finland regional Environment centre, Turku. 2007, pp. 5-115.

5. Lazaridou M., Spanos Th., Tsiridis A., Kadoglou I. Wastewater and phosphorus effects on the growth of berseem clover. In: Grassland Science in Europe Vol. 11, 2012, pp. 104-106.

6. Deru J., Van Eekeren N., De Boer H. Rooting density of three grass species and eight Lolium perenne cultivars. In: Grassland Science in Europe, Vol. 17, 2012, pp. 604-606.

7. Matthews D.J.,Moran B.M. Otte M.L. Zinc tolerance, uptake, and accumulation in the wetland plants eriophorum angustifolium, Juncus effusus, and juncus articulatu. In: Wetlands, vol.24, No.4, 2004, pp. 859-869.

8. Казмирук В. Д., Казмирук Т. Н. Методы доочистки сточных вод с использованием высшеи водной растительности, 5-я Международная конференция "Сотрудничество для решения проблемы отходов" 2008, $\begin{array}{llll}\text { c. 2-4, [tiešsaiste] [15.12.2011] Pieejams: } & \text { 2 }\end{array}$ http://waste.com.ua/cooperation/2008/theses/kazmiruk.html

9. Peruzzi E.,Macci C., Doil S.et.all. Phragmites australis for sewage sludge stabilization. In: Desalination 247, 2009, p. 119.

10. Adler A., Karacic A., Weih M. Biomass allocation and nutrient use in fast-growing woody and herbaceous perennials used for phytoremediation, In: Plant Soil 305, 2008, pp. 189-206.

11. Brix H., Arias C.A., Bubba M. Media selection for sustainable phosphorus removal in subsurface flow constructed wetlands. In:Water Science and Technology Vol 44 No $11-12,2001$, pp. 47-54.

12. Sim C.H. The use of constructed wetlands for wastewater treatment, ISBN: 983-40960-2-X. 2003, pp. 1-30.

13. Ye Z.H., Baker A.J.M., Wong M.H., Willis A.J. Zinc, Lead and Cadmium Tolerance, Uptake and Accumulation by the Common Reed, Phragmites australis (Cav.) Trin. ex Steudel. In: Annals of Botany 80, 1997, pp. 363-370.

14. Ali N.A., Bernal M.P., Ater M. Tolerance and bioaccumulation of copper in Phragmites australis and Zea mays, In: Plant and Soil 239, 2002, pp. 103-111.

15. Grisey E., Laffray X., Contor O. et.all. The Bioaccumulation Performance of Reeds and Cattails in a Constructed Treatment Wetland for Removal of Heavy Metals in Landfill Leachate Treatment (Etueffont, France). In: Water Air Soil Pollut 223, 2012, pp. 1723-1741.

16. Batty L.C., Baker A.J.M., Wheeler B.D., Curtis C.D. The Efect of $\mathrm{pH}$ and Plaque on the Uptake of $\mathrm{Cu}$ and $\mathrm{Mn}$ in Phragmites 
australis (Cav.) Trin ex. Steudel. In: Annals of Botany 86, 2000, pp. 647-653.

17. Oliveira J.S., FemandesJ.A., Alves C., Morais J., Urbano P. Metals in sediment and water of three reed (Phragmites australis (Cav.) Trin. ex Stend.) stands. In: Hydrobiologia 415, 1999, pp. 41-45.

18. Terry N, Sambukumar S., LeDuc D. Biotechnological approaches for enhancing phytoremediation of heavy metals and metalloids. In: Acta Biotechnol 23, 2003, pp. 281-288.

19. Raskin I, Kramer U, Smith R.D., Salt D.E., Schulman R. Phytoremediation and mechanisms of metal accumulation in plants. In: Plant Physiol 114, 1997, pp. 1253-1255.

20. Salt D., Smith R., Raskin I. Phytoremediation. In: Ann Rev Plant Physiol 49, 1998, pp. 643-668.

21. Lasage E., Rousseau D.P.L., Meers E. Et.all. Accumulation of Metals in the Sediment and Reed Biomass of a Combined
Constructed Wetland Treating Domestic Wastewater. In: Water Air Soil Pollut 183, 2007, pp. 253-264.

22. Adamovičs A., Dubrovskis V., Plūme I., Jansons Ā., Lazdiña D., Lazdiņš A. Biomasas izmantošanas ilgtspējības kritēriju pieleietošana un pasākumu izstrāde, Valsts SIA Vides projekti, Rīga, 2009, 1.-172. lpp.

23. Kozlowska M., Jozwiak A., Szpakowska B., Golinski P., Biological aspects of Cadmium and Lead uptake by Phragmites Australis (Cav.Trin Ex staudel) in natural water ecosistems. In: Journal Elementol 14(2), 2009, p.304-310.

24. Duman F., Cicek M., Sezen G. Seasonal changes of metal accumulation and distribution in common club rush (Schoenoplectus lacustris) and common reed (Phragmites australis). In: Ecotoxicology 16, 2007, pp. 457-463. 